\title{
SIGNIFICANCE OF FUNCTIONAL ORGANIZATION OF SETTLEMENTS FOR DEVELOPMENT OF PRIMARY RURAL SETTLEMENTS IN THE CITY OF ZAJEČAR
}

\author{
Vladimir PopovićA \\ Received: April 22, 2020 | Accepted: June 28, 2020 \\ DOI: 10.5937/ZbDght2001070P
}

\begin{abstract}
The aim of this paper is determination of the City of Zaječar settlements' functional organization characteristics significant for development of primary rural settlements on this territory. The paper examines truthfulness of a hypothesis that in conditions of extreme monocentrism, i.e. dominance of urban centre, development of primary rural settlements is in direct negative correlation with isochronous distance from the urban center. Secondary hypothesis is an assertion that primary rural settlements functionally connected to centers of communities of settlements as dispersly located microdevelopment centers are characterized by significantly more favorable development compared to settlements functionally connected to local rural centers or directly to the urban center. Methodologically, the paper is based on the comparison of development characteristic of primary rural settlements relative to their isochronous distance from the urban center and functional connections to higher rank settlements in the functional hierarchy. Selection of indicators was made in order of comprehensive representation of the most significant demographical and economical processes in these settlements caused by their geographical and functional positions. Perception of the significance of the isochronous distance from the urban center was made using Pearson correlation coefficient, and the method of comparison was used for the functional connections. The significance of this paper is in contribution to the insight of applicability of decentralized concentration concept on local territorial level in conditions of extreme monocentrism, i.e. dichotomy on relation rural-urban.
\end{abstract}

Keywords: functional organization of settlements, centers of communities of settlements, primary rural settlements, the City of Zaječar

A University of Belgrade, Faculty of Geography, Studentski trg 3/III, 11000 Belgrade, vpopovic.za@gmail.com 


\section{INTRODUCTION}

Functional organization of settlements of a particular area implies establishment of their functional hierarchy in accordance with existing or planned concentration of public services in them, as well as defining gravitation areas of central settlements established in that way. It is based on impossibility of equal and complete equipment of all settlements with necessary public services that enable quality life in them. In that circumstances it is necessary to dispose these facilities in a smaller number of dispersedly located settlements which in such a way become the carriers of development of their surroundings, i.e. less equipped settlements in them. Centrality of settlements as a measure of their spatial significance is based on these postulates. It is determined just by degree of equipment with public services, infrastructural accessibility, concentration of inhabitants and services and volume of daily circulation (Drobnjaković, 2019).

Researches in this domain are daiting back to 1933. and Christaller's central place theory. He recognizes centrality as a basic characteristic of a settlement, according to which he performs their distinction in functional hierarchical system. Christaller (1933) observed an urban settlement as a factor of space and population integration through its role and impact in organization of trade, traffic and administration. He guided himself by a principle that centrality is in the nature of organization of the space and human society. He defined it as the significance of one settlement in the development and concentration of functions intendend for population of other settlements (Tošić, 2012). Based on the concentration of such functions, settlemets are being positioned in spatial and functional hierarchy of settlements in particular territory. In the pursuit for a model by which a smaller number of higher ranked settlements will be connected with an optimal number of lower ranked centers, Christaller (1933) proposed that their deployment should be based on hexagon principle, where higher ranked settlements are located in their centers, and lower ranked settlements in their peaks. Marinović-Uzelac (2001) considers that the theory of growth and development poles is an upgrade of the theory of central funcions of urban settlements. Its creator Perroux (1955) claims that development is done through spreading from the points, i.e. poles of growth and development. The central place theory has been criticised and upgraded, but the concept of centrality has held as an important concept in geographical thought (Drobnjaković, 2019). Model of decentralized concentration as a newer term related to functional organization is based right on these principles, i.e. decentralization by polycentric system of settlements organization and creating a hierarchically homogenous system of centers (Tošić, 2011).

Rural development is considered as one of the largest modern development problems of the Republic of Serbia (Radovanović, 1999). Martinović and Ratkaj (2015) point out significance of carefully consideration of rural-urban relations for achieving sustaniable rural development, but also for diversification of rural economy and modernization of agricultiral produce. In developing countries, even though most of the rural population is included in agricultural activities, they do not imply just a simple produce (Ellis, 1998; Bebbington, 1999), and a modern concept of rural space usage implies more than agricultural activities (Mardsen, Adriansen, 2004). In such terms, functional organization of rural areas is set as necessary requirement for their sustainable development. In 
local self-government units spatial plans in the Republic of Serbia, with particular variations in accordance with specificities of concrete spatial unities, it is based on the following categories of central settlements (Tošić, 2011):

- centers of communities of settlements - settlements on higher hierarchical level, with a group of primary rural settlements in their gravitation areas. They are characterized by higher significance in a network of settlements, according to higher level of equipment with public services, but also with economical functions;

- rural settlements with center - settlements that may have own smaller gravitation area, with lower level of equipment with public services. (Tošić, 2011) points out that according to their traffic position and position in local settlement network they often represent singly centers, without a gravitation area and

- primary rural settlements - the smallest settlements by rule, mainly settled by agricultural population and daily migrants. They mainly have housing-economic character for the needs of their own population, without other facilities or external functions.

Drobnjaković (2019) focuses her research of development role of rural settlements in Central Serbia on a group of settlements considered endangered and devastated, because she starts from an assumption that integration of surrounding settlements with weak socio-economic potential can be affected by routing and appropriate actions towards sustainable and progressive settlements in rural area. She justifies that statement by a fact that there were very small investments in rural area of the Republic of Serbia over the past decades, and financial and institutional barriers are too big for equal treatment of every category of rural settlements. She points out that it is necessary to initially invest in partial areas that still manage to survive in aggravate rural circumstances for economy and social life, by which strengthening development impulses would spread towards direct and farther rural surrounding. Zvezdan, Grljan and Veliki Izvor, defined as secondary urban centers by local self-government unit spatial plan of the City of Zaječar are identified as such settlements, but they are excluded from this research, according to their proximity to the urban center, which they are even partially morphologically fused with. On the other hand, positions in functional hierarchy of settlements in the City of Zaječar are in some way confirmed to the centers of communities of settlements Rgotina and Salaš, so this paper will examine their so far impact on the development of primary rural settlements in their gravitation areas.

Accordingly, the aim of this paper is determination of the City of Zaječar settlements' functional organization characteristics significant for development of primary rural settlements on this territory. The basic hypothesis is represented by a statement that in conditions of extreme monocentrism, i.e. dominance of urban center, development of primary rural settlements is in direct negative correlation with isochronous distance from the urban center. Secondary hypothesis is an assertion that primary rural settlements functionally connected to centers of communities of settlements as dispersly located microdevelopment centers are characterized by significantly more favorable development compared to settlements functionally connected to local rural centers or directly to the urban center. 


\section{METHODOLOGY}

The City of Zaječar is a part of the Timok Krajina, a border territory with the Republic of Bulgaria and the Republic of Romania (Figure 1). According to its peripheral position within the Republic of Serbia and distance from significant development centers, the period of transition is marked by a collapse of economy and long-term regression which specially affected the rural settlements, known for its unfavorable development characteristics. Depopulation process, domination of elderly population, absence of economy and infrastructure investments are their characteristic in general. In such context, the territory of the City of Zaječar is considered suitable for the research, ac-

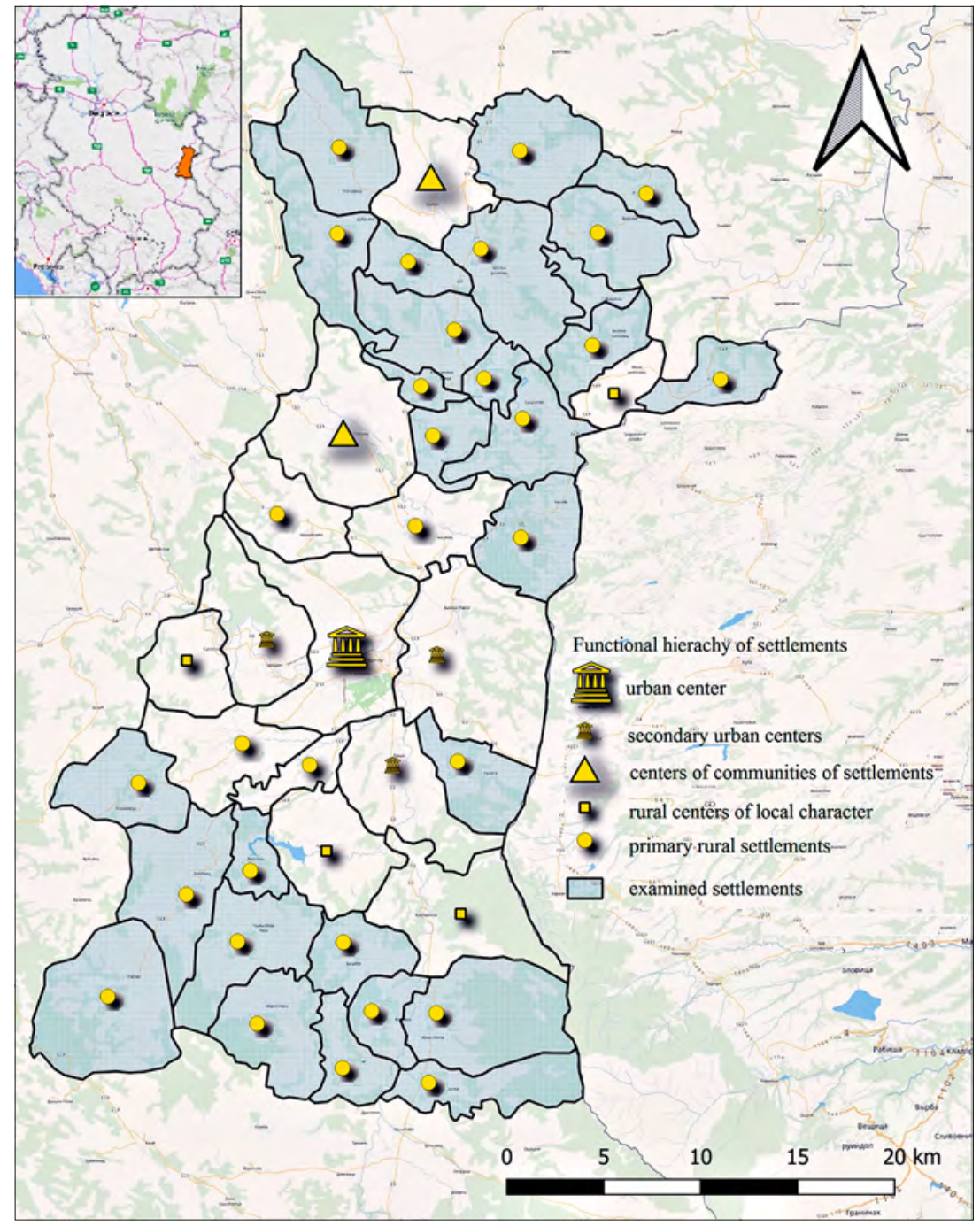

Figure 1. Examined area

Source: Author 
cording to extreme dominance of the urban center and vast area with relatively large number of settlements and significant distances of peripheral settlements form the urban center. Primary rural settlements are the object of this paper as the most numerous category of settlements, the lowest rank in functional hierarchy (which implies the lowest and identical level of infrastructure and public services equipment). Settlements in direct surrounding of the urban center are excluded from this research according to clear rationality of their functional connections with it, in order to obtain more credible research results. In that manner, examined sample is reduced to 28 settlements shown on Figure 1.

At the very beginning, it is important to admonish a restricted number of indicators caused by data availability on the level of individual settlements. In order to get relevant indicators, the data was analyzed for the period of 1981-2011., i.e. last three inter-census periods. In such circumstances, the following indicators were chosen as comprehensive and clear indicators of development processes on a specific area:

- Index of inhabitants' number change

- Index of households' number change

- Average annual net migration rate

- Percentage of employed in non-agricultural activities in total active population that performs an occupation in the year 2011 and

- Percentage of daily migrant workers to the urban center in total number of workers in the year $2011^{1}$.

According to the object, goal and hypothesis of the research, the process of research in methodological consists of the following steps:

- Determination of isochronous distances of the examined settlements from the urban centre, zoning based on five-minute distance ranges and their cartographic presentation (method of isochrones and cartographic method - based on QGIS 3.8.3 software);

- Division of the examined settlements in two groups: basic (functionally connected with belonging centers of communities of settlements) and control (functionally connected directly with the urban center or rural centers of local character);

- Correlation determination of isochronous distances of the examined settlements from the urban centre and their development characteristics by the chosen indicators in order to prove the basic hypothesis of the paper (method of proving by Pearson correlation coefficient). The values of isochronous distances of the examined settlements from the urban center are taken for the variable $\mathrm{x}$, while the values of the development indicators were taken for the variable y. Mathematically, the coefficient values shown in Table 2 . are obtained in the following manner:

1 The aim of processing of the last two indicators is to compare their values depending on the isochronous distance from the urban centre and the division in the basic and control group, having into account the role of the urban center as a dominant labor center 


$$
\begin{aligned}
& S S_{x x}=\sum_{i=1}^{n}\left(x_{i}-\bar{x}\right)^{2} \text { where } \bar{x}=\frac{1}{n} \sum_{i=1}^{n} x_{i} \\
& S S_{y y}=\sum_{i=1}^{n}\left(y_{i}-\bar{y}\right)^{2} \text { where } \bar{y}=\frac{1}{n} \sum_{i=1}^{n} y_{i} \\
& S S_{x y}=\sum^{n}\left(x_{i}-\bar{x}\right)\left(y_{i}-\bar{y}\right) \\
& r=\frac{S S_{x y}}{\sqrt{S S_{x x} \cdot S S_{x y}}}
\end{aligned}
$$

- Characteristics comparison of the basic and control group settlements by the chosen indicators in order to prove the secondary hypothesis of the paper (method of comparison).

\section{RESULTS}

The zoning of the examined settlements according to their isochronous distance from the urban centre and their division in the basic and control group (Figure 2) are previous steps for development indicators processing in this paper, i.e. hypothesis testing.

Pearson correlation coefficient was applied in order to determine correlation between isochronous distance of the examined settlements from the urban center and values of the development indicators.

Table 1. Directions for correlation coefficient value interpretation

\begin{tabular}{|l|c|c|c|c|c|}
\hline $\begin{array}{l}\text { Interpretation of } \\
\text { correlation }\end{array}$ & Very weak & Weak & Moderate & Strong & Very strong \\
\hline Value & $0-0,3$ & $0,31-0,5$ & $0,51-0,7$ & $0,71-0,9$ & $0,91-1$ \\
\hline
\end{tabular}

Source: Hinkle et al., 1988

Although high value of correlation coefficient does not imply cause-effect relation between two variables (it is not proven by the value, but high value can be basis of further research), low values of correlation indexes between two variables are a proof of an absence of cause-effect relation between them (Tables 1. and 2.). 


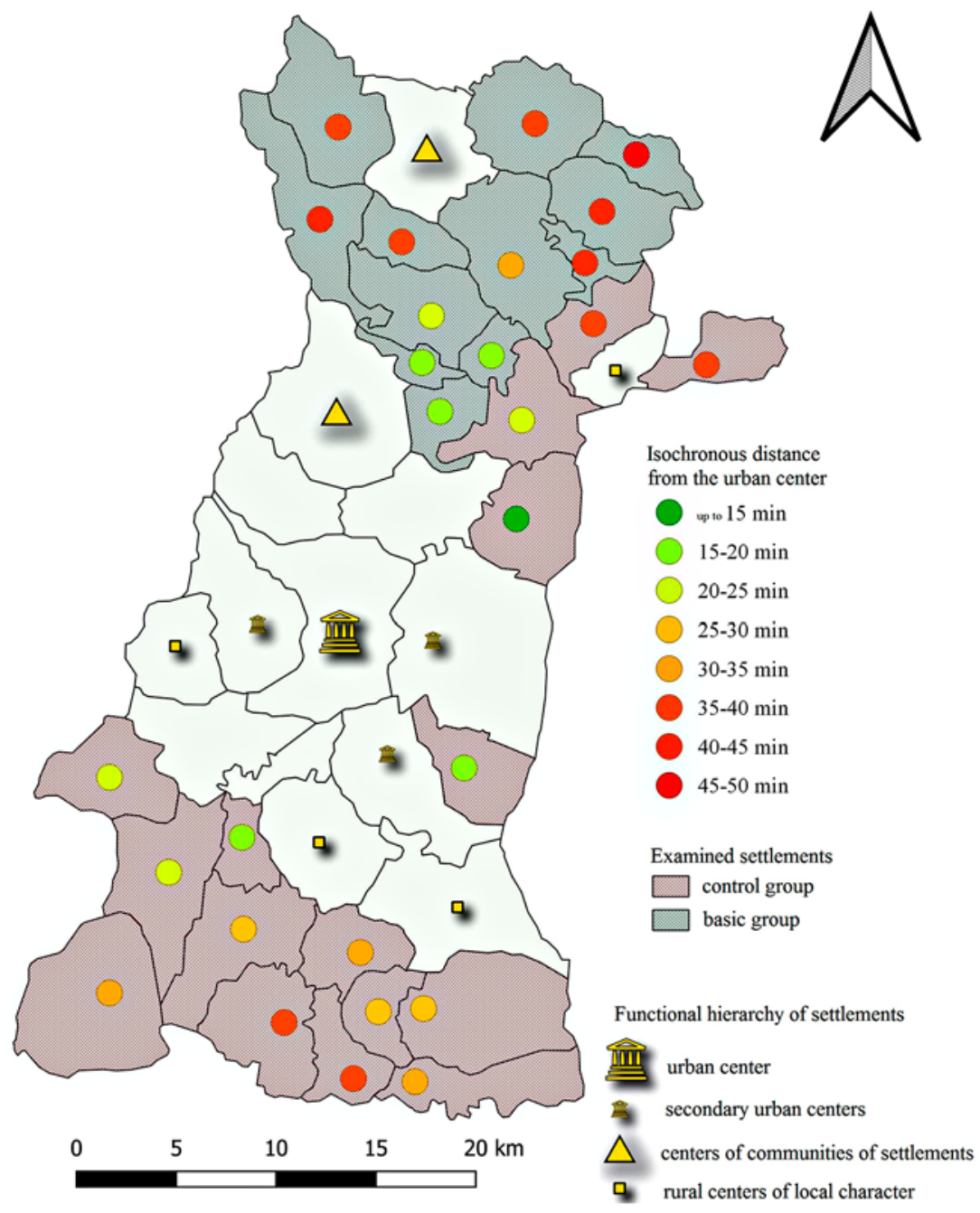

Figure 2. Division of the examined settlements in basic and control group and their isochronous distance from the urban center

Source: Author 
Table 2. Values of Pearson correlation coefficient of isochronous distance of the examined settlements from the urban center and values of the development indicators

\begin{tabular}{|l|c|c|c|c|c|}
\hline $\begin{array}{c}\text { Group of } \\
\text { settlements }\end{array}$ & $\begin{array}{c}\text { Index of } \\
\text { inhabitants' } \\
\text { number } \\
\text { change for } \\
\text { the period } \\
1981-2011 .\end{array}$ & $\begin{array}{c}\text { Index of } \\
\text { households' } \\
\text { number } \\
\text { change for } \\
\text { the period } \\
1981-2011 .\end{array}$ & $\begin{array}{c}\text { Average } \\
\text { annual net } \\
\text { migration } \\
\text { rate2 for the } \\
\text { period 1981- } \\
2011 .\end{array}$ & $\begin{array}{c}\text { Percentage of } \\
\text { employed in } \\
\text { non-agricultural } \\
\text { activities in total } \\
\text { active population } \\
\text { that performs an } \\
\text { occupation in the } \\
\text { year 2011 }\end{array}$ & $\begin{array}{c}\text { Percentage of } \\
\text { daily migrant } \\
\text { workers to the } \\
\text { urban center in } \\
\text { total number } \\
\text { of workers in } \\
\text { the year } 2011\end{array}$ \\
\hline Basic & $-0,49$ & $-0,48$ & $-0,60$ & $-0,83$ & $-0,77$ \\
\hline Control & 0,10 & 0,00 & 0,41 & $-0,34$ & $-0,45$ \\
\hline $\begin{array}{l}\text { All examined } \\
\text { settlements }\end{array}$ & 0,03 & 0,02 & 0,09 & $-0,53$ & $-0,60$ \\
\hline
\end{tabular}

Source: Author

Values of Pearson correlation coefficient of isochronous distance of the examined settlements from the urban center and values of the development indicators that refer to inhabitants' and households' number change and net migration rate are in range of very weak and weak correlation observing the examined settlements in whole, but also relative to their belonging to the basic or control group. The exception is the value of average annual net migration rate for the period 1981-2011. for the basic group of settlements, which is in the range of moderate negative correlation with isochronous distance from the urban center. The values of the development indicators that refer to economic characteristics in the case of the basic group are in the range of strong negative correlation, and in the case of the control group in the range of weak negative correlation. Observing the examined settlements in whole, the values of these two coefficients are in the range of moderate negative correlation. In the Table 3. there is a parallel review of the values relative to the belonging to the basic and control group.

Table 3. Comparative review of values of development indicators

\begin{tabular}{|l|c|c|}
\hline Development indicator & $\begin{array}{c}\text { Basic group of } \\
\text { settlements }\end{array}$ & $\begin{array}{c}\text { Control group of } \\
\text { settlements }\end{array}$ \\
\hline Index of inhabitants' number change for the period 1981-2011. & 51,12 & 37,64 \\
\hline Index of households' number change for the period 1981-2011. & 64,05 & 52,19 \\
\hline Average annual net migration rate for the period 1981-2011. & -6.34 & $-7,63$ \\
\hline $\begin{array}{l}\text { Percentage of employed in non-agricultural activities in total } \\
\text { active population that performs an occupation in the year 2011 }\end{array}$ & 28,12 & 24,72 \\
\hline $\begin{array}{l}\text { Percentage of daily migrant workers to the urban center in total } \\
\text { number of workers in the year 2011 }\end{array}$ & 36,17 & 73,54 \\
\hline
\end{tabular}

Source: Author

\footnotetext{
2 Vitally-statistical method is used for this calculation
} 
During the period of 1981-2011. the number of inhabitants of the basic group of settlements was reduced by $48,88 \%$, while the control group loses as many as $62,36 \%$ of the initially population. The number of households was reduced by $35,95 \%$ in the basic group and $47,81 \%$ in the control group of settlements. The average annual net migration rate differs for 1,29 . The percentage of employed in non-agricultural activities in total active population that performs an occupation in the year 2011. shows the difference of $3,4 \%$, while the difference between the percentages of daily migrant workers to the urban center in total number of workers in the year 2011. is $37,37 \%$.

\section{CONCLUSION}

Functional organization of settlements is an obligatory part of planning solutions in local self-government units spatial plans. It represents a significant instrument for optimal organization of activities and increase of life quality of a specified space. It is based on the concept of centrality and implies endeavor to provide quality access to public services to all inhabitants of a specific space and by that directly affect settlements development. According to that, the aim of this paper is determination of the City of Zaječar settlements' functional organization characteristics significant for development of primary rural settlements on this territory.

The basic hypothesis of this paper came out to be almost completely false. In conditions of extreme monocentrism, i.e. dominance of urban center, development of primary rural settlements shows low correlation with isochronous distance from the urban center. Values of Pearson correlation coefficient of isochronous distance of the examined settlements from the urban center and values of development indicators that refer to changes in number of inhabitants and households and net migration rate indicate absence of regularity in changes by growth of isochronous distance of the examined settlements from the urban center. Value of the coefficient for average annual net migration rate for the period 1981-2011. for the basic group of settlements, which is in range of moderate negative correlation with isochronous distance from the urban center goes in favor of proofing the secondary hypothesis, according to that it implies a decrease tendency of net migration rate with distancing from the urban center. As it is pointed out, high coefficient values for the indicators related to economy characteristic (especially in the case of the basic group) cannot be used for hypothesis proofing. On the other hand, regularly decrease in percentages of employed in non-agricultural activities in total active population that performs an occupation and daily migrant workers to the urban center in total number of workers with distancing from the urban center in the case of the basic group (while the coefficient values for the control group are in the range of weak correlation) clearly shows combined economic significance of the urban center, but also the centers of communities of settlements.

The secondary hypothesis, i.e. an assertion that primary rural settlements functionally connected to centers of communities of settlements as dispersly located microdevelopment centers are characterized by significantly more favorable development compared to settlements functionally connected to local rural centers or directly to the 
urban center came out to be conditionally correct. That is confirmed by clear differences between values of all examined indicators. Population decrease by two thirds in the control group of settlements is the most obvious proof of their extremely unfavorable development characteristics.

On the other hand, nor development characteristics of the basic group of settlements cannot be evaluated as favorable. Almost halved number of inhabitants in the examined period, with the decrease of average number of inhabitants per household, unfavorable average annual net migration rate, with the low percentage of employed in non-agricultural activities indicate insufficient capacities of the centers of communities of settlements to accomplish their role in integration and sustainable development of their gravitation areas.

Long term marginalization of rural planning, but also rural space in the broadest sense has brought to its altogether devastation. In order to provide quality life to inhabitants of primary rural settlements as a precondition of their sustainable development, in terms of functional organization, central settlements in which surroundings they are located should be equipped with wide range of high-quality public services according to their microdevelopment role. Development nucleuses in rural areas should be the leading rural settlements with strikingly characteristics: population mass, functional capacity, location and accessibility, centrality, integrative and development generators, with higher level of life quality. These settlements should represent functional cores and initiators of socio-economic transformations and urbanization of rural areas (Maksin et al., 2014). Considering present socio-economic circumstances, it is clear that there are many barriers on that road, as well as necessity of realization of many other conditions (primarily in political, economical and infrastructural sense) in order of achieving ascending development of rural settlements.

\section{REFERENCES}

Bebbington, A. (1999). Capitals and capabilities: a framework for analyzing peasant viability, rural livelihoods and poverty. World Development 27 (12), 2021-2044.

Christaller, W. (1933). Die zentralen Orte in Süddeutschland: Eine ökonomisch -geographische Untersuchung über die Gesetzmässigkeit der Verbreitung und Entwicklung der Siedlungen mit städtischen Funktionen. Doktor-Disertation. Reprinted 1980. Darmstadt.

Ellis, F., 1998. Household strategies and rural livelihood diversification. The Journal of Development Studies 325 (1), 1-38.

Hinkle, D., Wiersma, W., Jurs, S. (1988). Applied Statistics for the Behavioral Sciences. Boston: Houghton Mifflin Co.

Drobnjaković, M. (2019). Razvojna uloga ruralnih naselja Centralne Srbije. Beograd: Geografski institut „Jovan Cvijić“.

Maksin, M., Tošić, D., Krunić, N. (2014). Perspektive regionalnog prostornog planiranja u Srbiji. U Petrić, J., Vujošević, M., Hadžić, M., \& Bajat, B. (ur.) Obnova strateškog 
prostornog mišljenja, istraživanja i upravljanja u Srbiji. Posebna izdanja 74 (pp. 4578). Beograd: Institut za arhitekturu i urbanizam Srbije.

Mardsen, L. M., \& Adriansen, H. K. (2004). Understanding the use of rural space: the need for multi-methods. Journal of Rural Studies 20, 485-497.

Marinović-Uzelac, A. (2001). Prostorno planiranje. Zagreb: Dom Svijet.

Martinović, M., Ratkaj, I. (2015). Sustainable rural development in Serbia:Towards a quantitative typology of rural areas. Carpathian Journal of Earth and Environmental Sciences 10 (2), 37 - 48.

Perroux, F. (1955). Materiaux pour une analyse de la croissance économique. Fasc. 1. Paris: I.S.E.A.

Radovanović, S., 1999. Basic tendencies in demographic development of rural population and revitalization: related issues. Stanovništvo, 1-4, 9-24

Tošić, B. (2011). Osnove ruralnog planiranja. Beograd: Geografski fakultet.

Tošić, D. (2012). Principi regionalizacije. Beograd: Geografski fakultet.

Spatial plan of the City of Zaječar („The Official Gazette of the City of Zaječar“, no. 15/2012).

Census of Population, Households and Dwellings in the Republic of Serbia 2011., Census book no. 20. Comparative review of the number of inhabitants 1948-2011. Belgrade: Statistical Office of the Republic of Serbia.

Census of Population, Households and Dwellings in the Republic of Serbia 2011., Census book no. 21. Comparative review of the number of households 1948-2011. Belgrade: Statistical Office of the Republic of Serbia.

Census of Population, Households and Dwellings in the Republic of Serbia 2011., Special publication: Industry. Belgrade: Statistical Office of the Republic of Serbia.

Census of Population, Households and Dwellings in the Republic of Serbia 2011., Special publication: Daily migrations. Belgrade: Statistical Office of the Republic of Serbia.

\section{CONFLICTS OF INTEREST}

The author declared no potential conflicts of interest with respect to the research, authorship, and/or publication of this article.

(C) 2020 by the authors. This article is an open access article distributed under the terms and conditions of the Creative Commons Attribution (CC BY) license (http://creativecommons.org/licenses/by/4.0/). 